ARTICLE

Received 8 Dec 2016 | Accepted 20 Feb 2017 | Published 14 Mar 2017

\title{
Attitude change among U.S. adults after the Castro-Obama announcement: the role of soft power in agenda setting
}

Jami Fullerton ${ }^{1}$, Alice Kendrick ${ }^{1}$ and Sheri Broyles ${ }^{1}$

\begin{abstract}
The United States and Cuba made history in late 2014 by announcing the resumption of diplomatic relations. With the media coverage and social media content related to the announcements as a stimulus, this pre-post-study noted increases in U.S. adults' levels of perceived knowledge, salience of attributes, as well as attitudes toward Cuba after the joint proclamations. Results suggest that media coverage and social media content played major roles in influencing both public knowledge of and attitudes toward Cuba as a country. These first- and second-level agenda-setting effects are positioned within the Model of Country Concept as an example of soft power. The power of international media to affect both cognitive and affective evaluations among the citizens of one country about the government and citizenry of another is discussed. This article is published as part of a collection on soft power.
\end{abstract}

${ }^{1}$ Oklahoma State University, Tulsa, OK, USA 
S oft Power-the ability to influence international relations through attractive cultural, political and foreign policy channels rather than with military might or coercion (Nye, 2004) - has been on display in the recent positive and peaceful shift in relations between the United States and Cuba. A simultaneous December 2014 announcement by U.S. President Barack Obama and Cuban President Raul Castro kicked off a series of initiatives that began with the release of prisoners in both countries who had been accused of spying (DeYoung, 2014; Federal Register, 2015). As of this writing, the soft power policies toward the island nation have included the re-opening of respective embassies, the loosening of travel and commerce restrictions, the commencement of direct commercial flights between the countries and a historic visit of the first sitting U.S. president in almost a century (Davis, 2016a).

This study contributes to the literature on soft power by way of Fullerton's Model of Country Concept (Fullerton and Kendrick, 2017). Country concept is operationalized first with a country reputation scale (Yang et al., 2008; Passowet al., 2005) and second by a measure of country image. The study seeks to understand how reportage of government policy in the international media affects Country A's (United States) knowledge of and attitudes toward Country B (Cuba). Specifically, this article analyzes survey data of U.S. adults' attitudes toward Cuba before and after the presidential announcement of December 2014 using the agendasetting function of the media as a theoretical framework. Analysis focused on changes in cognition (first-level agenda-setting effects) as well as attitudes (second-level agenda-setting effects) among U.S. citizens toward the neighbouring nation-changes that may have been triggered by the heavy media coverage of the presidential pronouncements regarding the soft power initiatives taken by both countries toward the other.

\section{U.S.-Cuba relations}

Cuba and the United States share a complicated history, going back to before the Spanish American War when the United States interceded to win Cuba's independence from Spain (Perez, 1990). The Cuban Revolution of 1959 installed Fidel Castro's communist rule, nationalized millions of dollars of U.S. business and manufacturing interests in Cuba and resulted in a cessation of trade (Suddath, 2009). The revolution launched an era of hostility between the two nations that lasted more than five decades. This period was highlighted by a series of contentious encounters between the two governments including the unsuccessful Bay of Pigs invasion by U.S. troops, the Cuban Missile crisis of 1962 and the return to Cuba from Miami of a 6-year-old refugee Elian Gonzalez, whose mother drowned in an attempt to escape to the United States (Barringer, 2000). The ideological differences, military conflicts, nationalization of U.S. interests and media coverage of the erosion of diplomatic ties resulted in a show of hard power-comprehensive trade embargo and severe restrictions on travel to Cuba by Americans. The embargo and travel ban became, according to some, "the linchpin of the U.S.-Cuba relationship" (Whitefield, 2014, para. 29).

However, the embargo period-from the beginning-was not without intermittent efforts to reconcile. According to Cuban/American scholars LeoGrande and Kornbluh, almost every president since Eisenhower attempted some level of dialogue and reconciliation with Cuba, although most were done in secret through "back channel" diplomacy to avoid political sensitivities (LeoGrande and Kornbluh, 2014: 3). Many of these efforts by the U.S. government were politically unpopular and loudly opposed by the Cuban-American lobby based in south Florida, who vehemently rejected reconciliation between the two countries.
Florida's Cuban exile community, who once plotted to overthrow Fidel Castro and regularly channelled money to dissidents, reliably vote Republican, partly because of the GOP's anti-communist position. Younger Cuban-Americans, many born after the 60s-era policies were put in place, have different views toward the Castro regime, are more concerned with current and future economic opportunities with their former country and have elected some Democrats in Florida (Leatherby, 2015). Ongoing tracking of Cuban Americans living in South Florida by the Florida International University (https://cri.fiu.edu/research/ cuba-poll/) taken in 2014 (about six months before the joint presidential announcement) revealed increasing support for improved relations between the U.S. and Cuba, especially among younger Cuban-Americans. The generational and ideological shift in attitudes of Cuban-Americans has been cited as one factor that allowed for the normalization in diplomatic relations between the two countries (Cuban Research Institute, 2014).

Dating back to 1960, American sentiment towards Cuba reflected the countries' status as Cold War enemies, but in recent years a thaw in relations became apparent (Whitefield, 2014). Fidel Castro, citing poor health, ceded control of Cuba to his brother Raul in 2008 (McKinley, 2008), and died in 2016. Raul was seen as a potentially more moderate leader open to social and economic reform as well as to mending relations with the United States (Neill, 2008). The so-called "Obama Doctrine," which emphasizes collaboration and negotiation, and questions why historic U.S. enemies must remain U.S. enemies (Goldberg, 2016) was put in to play with respect to Cuba early in President Obama's administration when he reportedly told aides shortly after his 2008 election that they needed to "design a play to run with Cuba" (Kornbluh et al., 2015). This led to a series of secret talks over several years headed by top Presidential aides Benjamin Rhodes and Ricardo Zuniga and included "a handful of dedicated U.S. legislators, well-financed lobbyists, Alan Gross' aggressive legal team, an activist pope from Latin America, and a woman hell-bent on getting pregnant" (Kornbluh et al., 2015, para 6).

So, it was no surprise to some that on 17 December 2014, simultaneous announcements were made by U.S. President Barack Obama and Cuban President Raul Castro that signalled the birth of a new relationship between the two nations (DeYoung, 2014). Statements included plans for the release of prisoners in both countries who had been incarcerated since the 1990s on allegations of spying, as well as the introduction of less rigorous restrictions on both family and business travel (Ahmed and Davis, 2015). The new diplomatic relationship spurred additional changes over the following year-and-a-half including re-opening of respective embassies, removal of Cuba from the state-sponsored terrorism list (Davis, 2015), commencement of commercial flights from Florida to Cuba ("First), allowance by presidential executive order for U.S. citizens to bring unlimited amounts of Cuban cigars and rum back into the United States for personal consumption (Gomez, 2016) and a state visit by President Obama and his family to the country in March 2016-the first U.S. president to do so since Calvin Coolidge (Cave, 2016).

The U.S. presidential visit, though it did not result in major concessions on points of contention that included Cuban human rights issues (Robles, 2016) and economic freedom, was characterized nonetheless by multiple private meetings between President Obama and President Raul Castro as well as diplomatic statements from the leaders, including President Obama's statement about his desire to end the travel and trade embargoes (Davis, 2016a). Obama's visit was denounced by communist party hardliners, including Fidel Castro himself, as "honey-coated," dismissive of achievements of communist rule and intended to weaken the Cuban government (Frank, 2016). 
Eight months after the Obamas' visit, in November 2016 Republican Donald Trump's election as U.S. president was closely followed by the death of long-time dictator Fidel Castro. The change in U.S. administrations may result in the interruption or even reversal of the diplomatic steps made by the Obama administration, which could easily be done since most were by executive order rather than Congressional mandate (Davis, 2016b). On the other hand, the death of the one-time top U.S. enemy Fidel Castro may increase the popularity of Cuba among Americans (Moss, 2016).

It should be noted that recent developments in 2016, including President Obama's visit, the election of Donald Trump as U.S. president, Trump's less-than-positive remarks about future U.S. Cuba relations and the death of former Cuban president Fidel Castro, did not factor in the current study. These developments may likely factor in measures of country concept in future studies.

\section{Favorability ratings}

The Gallup Organization, which has noted gradually higher U.S. favorability ratings of Cuba for the past 20 years, in 2016 announced that for the first time since its measurement of such attitudes began (in 1996 with an $81 \%$ unfavorability rating), those who were favourable toward Cuba (54\%) outnumbered those who held unfavourable attitudes (Norman, 2016). Much of the increase in favourable views towards Cuba has been among Democratic and Independent party members in the United States (Norman, 2016). A New York Times survey of U.S. citizens in March 2016 found that 62 percent favored abolishing the ban on trade (Sussman, 2016). In Cuba, a 2015 survey by the international polling firm Bendixen and Amandi among Cuban residents reported almost unanimous (97\%) support in favour of normalizing relations with the United States, and that most also favour economic reform (Partlow and Craighill, 2015).

Perhaps more important to allowing the change in policy by the U.S. government was the attitude shift by Cuban-Americans living in South Florida. The on-going tracking by the Florida International University (https://cri.fiu.edu/research/cuba-poll/) revealed in 2014 that $68 \%$ favored the establishment of diplomatic relations with the U.S, and among those under $30,88 \%$ were in favour of establishing diplomatic ties with the country of their heritage. The 2014 poll also showed that just less than half of South Florida's Cuban-Americans favored continuing the embargo, down from $88 \%$ in 1991. For those between 18-29 years of age, only $8 \%$ thought the embargo should continue.

\section{U.S. soft power and Cuba}

During and following the diplomatic announcement, many in Washington and Miami noted that the five-decade hardline stance of isolation and pressure toward Cuba had not seemed to work in bringing democracy and improved human-rights to the Cuban people and suggested that it might be time for a softer approach. Many supported the notion that soft power initiatives, such as opening travel and commerce, might work in the case of Cuba, including the top Obama official who brokered the diplomatic deal, Ben Rhodes. In an interview with the Atlantic (Goldberg, 2016), Rhodes said, "by opening up... you're going to empower the Cuban people. They're going to get more resources; they're going to have more interconnectivity to the rest of the world". Rhodes also spoke about engagement-a tenet of soft power-as a purposeful strategy for promoting democracy and human rights (Goldberg, 2016). People-to-people contact, whether with the U.S. diplomatic corps in the newly opened U.S. embassy, with U.S. students and scholars through educational and cultural exchanges, or with U.S. business people through more open business opportunities, will allow Cubans to experience U.S. democracy and freedom firsthand.

Mediated engagement, including exposure to U.S. exported entertainment and news, may be another form of soft power. Part of the 2014 deal between the two governments included Cuba agreeing to increase Internet access to its people-a fact that provides more evidence that soft power strategies were part of the plan to achieve U.S. objectives. Almost immediately following the diplomatic announcement, Netflix announced streaming services to Cuba (Glenza, 2015) although initial cost was out of reach for most Cubans. A few months after the announcement, Conan O'Brien filmed his late night show in Havana (de Moraes, 2015). The Cuban people's exposure to U.S. popular culture, film, music and TV is thought to be strong soft power tool for winning Cuban hearts and minds. Exporting popular culture was a strategy widely used during the Cold War and one that some scholars claim played a significant role in bringing down the USSR (Bogart, 1995).

The focus of this study-U.S. attitudes toward Cuba as a result of U.S. policy shifting from hard to soft power-raises some interesting questions about the role of soft power initiatives by a country towards a former foe in shaping public opinion among the people of its own country.

\section{U.S. media content and Cuba}

To study the effects of news coverage on attitude change, it is necessary to understand the quantity and content of news coverage about the topic under study. Pérez (2008) cited the role of political cartoons as well as government statements over several decades that witnessed Cuba's depiction in U.S. media as a friendly neighbour to a troublesome foreign land monitored by the United States. Palmer (2011) cited the media's use of formulaic frames to depict Cuba's leaders and their political struggles with the United States. His textual analysis of print journalism found repeated characterizations of Cuban leaders as "hyper-masculine $\ldots$ as insufficient leaders because of their emphasis on violence and force" (p. 13).

Long-time Cuban ruler Fidel Castro has been the principal focus of much U.S. media coverage. In their content analysis of New York Times coverage of world leaders from 1950 to 2008, Gorman and Seguin (2015) established that Fidel Castro was the second-most covered foreign leader with almost 12,000 articles. The researchers concluded that conflict and negative developments commanded significantly more news attention than international cooperation.

In a study of U.S. television news coverage of Cuba at the end of the Cold War Soderlund et al. (1998) revealed a consistently negative valence of news about the island nation's role in international affairs, its political system, Fidel Castro specifically and the country of Cuba in general, citing that $62 \%$ of U.S. television news stories in 1992 about Cuba were negative. U.S. mainstream media coverage of Cuba in the twenty-first century had been spotty until 2014 when news of warming relations started to appear in the press. Various news outlets suggested in 2014 that clandestine meetings were taking place between the U.S. and Cuban governments, although there remained a prohibition against official negotiations.

For the purposes of positioning this study in terms of U.S.Cuba media coverage, it is important to understand the amount of U.S. media content around the date of the presidential announcement and how it changed over time. News of Cuba seemed to dominate the U.S. media immediately following the announcement. For example, chronological tracking of news stories on NBC shows 27 stories in the first 30 days following the announcement ("U.S. Cuba Relations) - a pace of about one story 
per day. In March 2015, Conan O’Brien filmed his late-night talk show in Cuba - the first time a U.S. television talk show host had visited the country since 1962 and 3.7 million viewers tuned in (de Moraes, 2015).

A search of Google News revealed about 10,100 news stories about Cuba on the day of and day after the announcement alone. A Google News search of "Cuba" five months prior to the premeasure in this study (17 January 2014-17 June 2014) revealed about 443,000 articles versus the same search five months prior to the post-measure (5 December 2014-5 May 2015), which included the announcement date, and produced 710,000 stories. Although a Google News search may be an imprecise measure, it indicated that coverage increased $60 \%$ leading up to and following the historic announcement versus earlier in the same year. A similar search of the New York Times archives over the same period revealed an even larger increase in stories about Cuba from 46 to 214 -almost a five-fold difference. There were 27 stories alone the 2 days following the announcement in New York Times, which had produced regular coverage in the months leading up to the diplomatic announcement.

Social media exploded with Cuba-related content as well. A few days after the announcement in December 2014, "cigar" received approximately 3,000 mentions on Twitter (Frumin and Margolin, 2014). Groshek et al. (2015) attempted to capture country image of Cuba between January and July 2015 by applying an algorithmic programme among 4.4 million Cuba-related tweets generated by 1.1 million users of Twitter who posted about Cuba during that period. Ten major topics were identified as country concept indicators, the most important of which were posts about political figures involved in the announcement, Cuba's trading partners, prisoner exchange, diplomatic relations, and travel as well as current news about a U.S. orchestra performing in Cuba and Cuba's offer to share its breakthrough lung cancer vaccine.

While this study does not include a formal content analysis of the news coverage, nor could such a study be located, commentary by U.S. media critics noted dramatic shifts in the tone of Cuba-related news just prior to and immediately following the presidential announcements. Several critics who commented on U.S. media coverage during that time noted a more upbeat and positive sentiment in news stories about U.S.Cuba relations, characterizing it as "celebratory narratives" (Perez, 2016, para. 6), "a positive shift" (Bolender, 2015, para. 1) and a "new air of legitimacy granted to Cuban interests" (O'Day, 2015, para. 8). The very crux of the news was indeed a positive milestone in U.S.-Cuba relations, and therefore the preponderance of coverage appeared to lack the negativity that had characterized much media content about Cuba in previous years.

\section{Theoretical framework}

The model of country concept. This study contributes to the growing body of work on soft power. Using Fullerton's Model of Country Concept (Fullerton and Kendrick, 2017, See Fig. 1), the study seeks to understand how information concerning government policy in the international media affected U.S. (Country A) attitudes toward Cuba (Country B).

Various components, or integrants of the The Model of Country Concept may or may not be under the control of a person or entity, referred to as an agent, that would attempt to influence a country's image. Among the uncontrollable contributors to country concept are international politics, past relationships between and among countries, natural disasters, man-made disasters such as war, economic developments and foreign media, including social media. Those elements of the

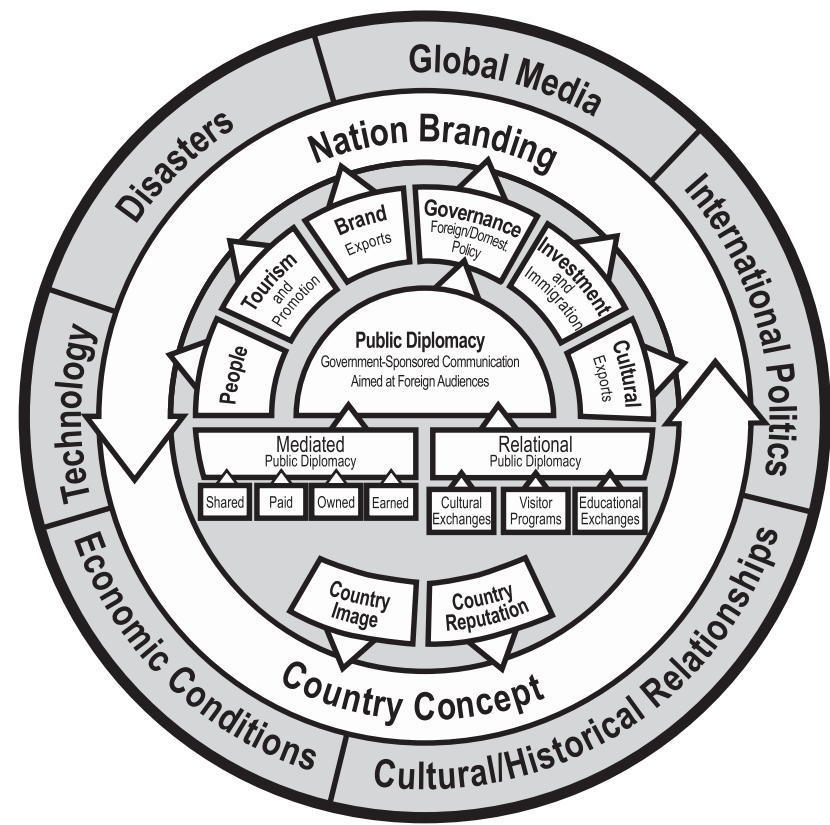

Figure 1 | The model of country concept

model that may fall under a measure of control by agents include exported products both manufactured and cultural, public diplomacy, citizen diplomacy, business diplomacy and tourism marketing communications. The outcome of the public's internalization of media content, direct or indirect experiences, entertainment programming and media, as well as current and past global political and economic developments is the conceptualization of nations among citizens of other countries. According to Fullerton (Fullerton and Kendrick, 2017), country concept derives from the dual measures of a country's reputation and also the country image that exists in the mind of a global citizen. (See Fig. 1 for a copy of the model.)

The case of the United States and Cuba can be placed on the model by first examining the external environment. Certainly the long and troubled historic relationship created a climate in which the two countries struggled to reconcile; however, recent international politics and the coverage of these developments in the international press have introduced new environmental elements that challenge the relationship. Given the environment - purposeful soft power policy changes (located on the Model of Country Concept within the governance element) on behalf of the Obama administration and transmitted to the general public via media coverage and content-the model depicts integrants that have the power to affect potential shifts in country concept among Americans toward Cuba. Through a pre/post survey of U.S. adults this study attempts to measure attitudinal changes by examining prior and current perceptions of country reputation and country image on the part of Americans about Cuba.

Agenda setting and country concept. This study is unique in that it is among one of the first attempts to test the Model of Country Concept by using the 17 December 2014, announcement as a stimulus for potential increase in knowledge about and attitude change toward a country. Because the analysis attributes the shift to a widely covered media announcement of governmental policy, the agenda-setting function of the press is important to the discussion.

At its most basic level, agenda-setting theory (McCombs and Shaw, 1972) explains how the media influence public opinion. Citizens are confronted with massive amounts of news and 
information via the media on a daily basis. The media selectively stress some information over others. Research over the last 50 years continues to support the notion that what the public believes is important, to a large extent, is driven by the media agenda. In essence, the media do not tell people what to thinkbut do tell them what to think about. The agenda-setting theory also confirms what Lippmann (1922) observed in-that most people have little firsthand experience with important matters such as international politics and therefore mass communication creates "pictures in our heads" about the world around us.

First-level agenda-setting research has focused on the transfer of salience about specific topics, or objects, covered in the news media and subsequently adopted by the public. The ability of the media to situate what Kosicki (1993) referred to as a "shell of a topic" (p. 112) on the public agenda by focusing reportage on that particular issue was the subject of many early agenda-setting studies.

McCombs and Shaw wrote in a lengthy paper in 1974 about the ability of the press to change attitudes and early failed attempts to show an effect (most notably Hovland's war film studies and Lazarsfeld's Erie County study). McCombs and Shaw wrote, "While little attitude change was found, these studies did find substantial communication impact on cognitions. It is this cognitive impact of mass media-the ability of the mass media to shape our map of the world..." (p. 1).

The current study attempts to visualize aspects of U.S. citizens' map of the world by measuring shifts in perceived knowledge of Cuba, and also looks at effects on attitudes. As agenda-setting research developed to include second-level agenda setting-and as salience and framing and methodological approaches became more sophisticated -evidence of attitude change became apparent. Iyengar and Kinder (1987) conducted experiments with the American public to measure the effects of priming during the evening news and found the public cared more about and had stronger feelings for issues and problems that were assigned greater importance on the evening news. Noelle-Neumann and Mathes (1987) pointed to the importance of the tone of media coverage and the potential effects it could have in influencing public sentiment toward an issue. They argued that beyond the basic transfer of salience of an issue from the media to the public, the media also contributed to a "climate of opinion which the population perceives as prevailing on a given subject" (p. 391)

Later, Moon (2011) further linked first- and second-order agenda setting to political attitudes and behaviour through the C-A-B model-a persuasion model that assumes cognitive effects lead to affective effects and likewise ultimately to behavioural considerations (Baran and Davis, 2015). Moon posited that the public gives more thought to issues that they regard as important because of the agenda set by the media. Likewise, the more important an issue, the stronger are attitudes toward that issue. As Zhang and Meadows (2012) noted in their triangulation of agendas of the White House, media and public: "Our findings support the postulate that the news media is a diplomatic device as powerful as formal policy statements. This conclusion can be observed in two ways. First, in terms of first-level agenda setting, a nation's visibility in media, which is the total frequency of news in the media, is able to influence the public's perception of a country. Second, in terms of second-level agenda setting, an attribute of a country, such as negative valence, is able to evoke negative attitudes toward the country" (p. 92). The authors emphasized the role of a "trigger event" in the agenda-setting process, which in the current study is the announcement of the warming of relations between the United States and Cuba in late 2014

One weakness of agenda-setting research is the suggestion of a causal relationship between news stories and public attitudes, mostly because agenda-setting research traditionally uses correlational studies only after an issue has been widely covered in the media. This study attempts to overcome that weakness and measures self-reported knowledge and attitudes before and after the widely covered announcement. While still unable to provide proof of cause and effect, it serves to strengthen the relational evidence and show changes in attitudes.

Specifically, the study explores the following questions:

1. Did perceived knowledge of Cuba change among U.S. adults after the presidential announcements about diplomatic relations between the two countries and, if so, how?

2. Did attitudes toward the Cuban government and Cuban people change among U.S. adults after the presidential announcements about diplomatic relations between the two countries and, if so, how?

3. Did Cuba's Country Concept change among U.S. adults after the presidential announcements about diplomatic relations between the two countries and, if so, how?

\section{Methods}

A pre-post quasi-experiment was conducted among a national sample of U.S. adults drawn from the same panel that were surveyed in June 2014 (6 months preannouncement) and in May 2015 (five months post-announcement) using Zoomerang's online survey platform. An identical instrument was used in both surveys (pre- and post-announcement).

Sample. A total of 628 U.S. adults participated in the study- 321 before the presidential announcement and 307 after the announcement. Respondents in the pre- and post-measurements were not the same people, but rather two samples drawn from the same large population pool of online panel members. Because the treatment-the joint announcement of improved diplomatic relations with Cubawas widely and evenly distributed throughout the United States, two large, representative samples selected pre and post could be expected to produce findings similar to a pre/post test with identical subjects.

Instrument. Identical questionnaires were administered in the pre and post data collection so that direct comparisons could be made between the two periods. To measure the dependent variable-Country Concept-the study employed a slightly adapted country reputation scale (Yang et al., 2008) consisting of 23 Likert-type statements measured on a 7-point scale from "very favorable" (7) to "very unfavorable" (1) (See Table 1) along with an open-ended question that asked respondents to write "three words" that came to mind when they thought of Cuba to measure country image. Attitudes toward Cuba and the Cuban people and government were adapted from Pew's Global Attitude Study (2010) and were measured on a 4-point scale. Knowledge about Cuba was measured on a 5-point scale with a single item.

\section{Results}

Respondent profile. The pre and post respondent groups were statistically compared and no significant differences were found in terms of demographic variables including gender, income, state in which they lived, level of education, having visited Cuba or having Cuban friends. The post-announcement sample-as-awhole was somewhat younger (Mean Age $=45.0$ years) versus the pre-announcement group (Mean Age $=48.5$ years; $p=.002$ ). All 628 respondents were analyzed together to produce the following profile:

Fifty-two percent of the respondents were female and $48 \%$ were male. Average annual household income for respondents ranged from less than $\$ 2,500$ to more than $\$ 200,000$ with a median income of $\$ 61,250$. Highest level of education achieved was $17.0 \%$ high school; $21.8 \%$ some college; $13.1 \%$ associates degree; $30.9 \%$ bachelors degree; and $15.5 \%$ graduate degree. Only 4 percent had visited Cuba, but about one-fifth (20.9\%) said they had "friends or acquaintances who are Cuban". The survey did not distinguish between Cubans who live in the United States and those who live in Cuba. 
1. Did perceived knowledge of Cuba change among U.S. adults after the presidential announcements about diplomatic relations between the two countries and, if so, how?

Respondents were asked to indicate their agreement with one item to measure perceived knowledge of Cuba, "I have a lot of

\section{Table 1 | Results of factor analysis (Varimax Rotation) for country reputation}

\begin{tabular}{|c|c|c|}
\hline \multirow[b]{2}{*}{ Retained Factors and Items } & \multicolumn{2}{|c|}{ Factors } \\
\hline & 1 & 2 \\
\hline \multicolumn{3}{|l|}{$\begin{array}{l}\text { Factor 1: Leadership } \\
\alpha=0.963 ; 56.6 \% \text { variance explained }\end{array}$} \\
\hline Cuba has a well-developed industrial sector & 0.703 & 0.376 \\
\hline Cuba is a safe place in which to invest & 0.706 & 0.417 \\
\hline Cuba is a democratic country & 0.766 & -0.039 \\
\hline I trust Cuba as a country & 0.809 & 0.305 \\
\hline Cuba has a good infrastructure & 0.845 & 0.218 \\
\hline Cuba is well managed & 0.861 & 0.197 \\
\hline Cuba maintains a stable economic environment & 0.825 & 0.209 \\
\hline $\begin{array}{l}\text { Cuban leaders communicate an appealing vision of } \\
\text { the country }\end{array}$ & 0.778 & 0.197 \\
\hline Cuba supports good causes & 0.821 & 0.274 \\
\hline $\begin{array}{l}\text { Cuba is a responsible member of the global } \\
\text { community }\end{array}$ & 0.855 & 0.227 \\
\hline Cuba supports responsible environmental policies & 0.807 & 0.290 \\
\hline Cuba has charismatic leaders & 0.632 & 0.267 \\
\hline Cuba upholds international laws & 0.846 & 0.175 \\
\hline I respect Cuba & 0.713 & 0.430 \\
\hline \multicolumn{3}{|l|}{ Factor 2: Culture } \\
\hline \multicolumn{3}{|l|}{ Alpha $=.894 ; 11.72 \%$ Variance Explained } \\
\hline Cuba is a beautiful place & 0.139 & 0.833 \\
\hline Cuba has an appealing culture & 0.263 & 0.841 \\
\hline Cuba offers enjoyable entertainment activities & 0.439 & 0.723 \\
\hline Cuba has a distinct culture & 0.038 & 0.796 \\
\hline Cuba has a rich historical past & 0.087 & 0.809 \\
\hline Items Not Retained & 1 & 2 \\
\hline Cuba has well educated residents & 0.521 & 0.600 \\
\hline I like Cuba as a country & 0.458 & 0.682 \\
\hline Cuba is an inviting place to do business & 0.674 & 0.442 \\
\hline Cuba is culturally and socially diverse & 0.441 & 0.592 \\
\hline
\end{tabular}

knowledge about Cuba". Independent sample t-tests revealed a significant increase in perceived knowledge of the country among Americans pre- and post-announcement $\left(M_{\text {pre }}=3.15\right.$; $\left.M_{\text {post }}=3.52 ; \mathrm{t}=-2.74(626), p=.006\right)$.

2. Did attitudes toward the Cuban government and Cuban people change among U.S. adults after the presidential announcements about diplomatic relations between the two countries and, if so, how?

Two separate questions were asked to measure attitudes toward the people and government of Cuba. "How favorable or unfavorable do you feel about the people of Cuba?" and "How favourable or unfavourable do you feel about the government of Cuba?" were measured on a four-point scale from very favourable (4) to very unfavourable (1). Respondents were also allowed to check "Don't know/Don't want to answer" and those who did were removed from the analysis. Independent samples t-tests showed that attitudes toward the Cuban people increased significantly $\left(M_{\text {pre }}=2.78 ; M_{\text {post }}=3.00\right.$; $t=-3.28$ (525), $p=.001$ ) following the announcement, as did attitudes toward the Cuban government $\left(M_{\text {pre }}=1.60\right.$; $M_{\text {post }}=1.91 ; t=-4.23$ (523), $\left.p=.0001\right)$.

3. Did Cuba's Country Concept change among U.S. adults after the presidential announcements about diplomatic relations between the two countries and, if so, how?

For this study, the two theoretical dimensions of Country Concept-Country Reputation and Country Image-were measured separately. Country Reputation was measured using a 23item 7-point Likert-scale from Strongly Agree (7) to Strongly Disagree (1). Country Image was measured by asking respondents to provide three words that came to mind when they thought of Cuba.

Country Reputation items (Cronbach's $\alpha=.964$ ) were factor analyzed and produced two underlying dimensions of Leadership and Culture (see Table 1 for item loadings and see Table 2 for mean scores and standard deviations). An independent samples t-test revealed significant increases on both dimensions following the presidential announcement (for Leadership: $M_{\text {pre }}=3.08$; $M_{\text {post }}=3.52 ; t=-4.30 \quad(626), \quad p=.0001$ and for Culture: $\left.M_{\text {pre }}=4.80 ; M_{\text {post }}=5.13 ; t=-3.32(626), p=.001\right)$.

Table 2 | Mean scores and standard deviations pre/post announcement

\begin{tabular}{|c|c|c|c|c|}
\hline Retained Factors and Items & Pre mean * & Pre SD & Post mean * & Post SD \\
\hline Factor 1: Leadership & 3.08 & 1.197 & 3.52 & 1.375 \\
\hline Cuba has a well-developed industrial sector & 3.57 & 1.320 & 3.90 & 1.547 \\
\hline Cuba is a safe place in which to invest & 3.07 & 1.401 & 3.64 & 1.567 \\
\hline Cuba is a democratic country & 2.30 & 1.549 & 2.73 & 1.777 \\
\hline I trust Cuba as a country & 2.753 & 1.459 & 3.32 & 1.660 \\
\hline Cuba has a good infrastructure & 2.95 & 1.365 & 3.33 & 1.590 \\
\hline Cuba is well managed & 2.78 & 1.452 & 3.28 & 1.674 \\
\hline Cuba maintains a stable economic environment & 3.26 & 1.523 & 3.628 & 1.624 \\
\hline Cuban leaders communicate an appealing vision of the country & 2.92 & 1.576 & 3.46 & 1.717 \\
\hline Cuba supports good causes & 3.20 & 1.466 & 3.59 & 1.598 \\
\hline Cuba is a responsible member of the global community & 3.13 & 1.492 & 3.57 & 1.630 \\
\hline Cuba supports responsible environmental policies & 3.29 & 1.426 & 3.64 & 1.563 \\
\hline Cuba has charismatic leaders & 3.29 & 1.779 & 3.70 & 1.747 \\
\hline Cuba upholds international laws & 3.08 & 1.502 & 3.40 & 1.641 \\
\hline I respect Cuba & 3.50 & 1.647 & 4.10 & 1.672 \\
\hline Factor 2: Culture & 4.80 & 1.248 & 5.13 & 1.255 \\
\hline Cuba is a beautiful place & 5.00 & 1.423 & 5.38 & 1.384 \\
\hline Cuba has an appealing culture & 4.44 & 1.636 & 4.83 & 1.576 \\
\hline Cuba offers enjoyable entertainment activities & 4.09 & 1.557 & 4.61 & 1.564 \\
\hline Cuba has a distinct culture & 5.37 & 1.310 & 5.52 & 1.355 \\
\hline Cuba has a rich historical past & 5.09 & 1.593 & 5.32 & 1.526 \\
\hline
\end{tabular}

${ }^{\star}$ Measured on a 7-point scale from strongly agree (7) to strongly disagree (1). 
To measure Country Image, respondents were asked to provide three words that came to mind when they thought of Cuba. The three words were sorted into 44 categories by independent coders (inter-coder reliability $=.933$ ). In the pre- and post-groups, the three words most often mentioned out of a total of 787 mentions in the pre and 718 in the post were Cigars (pre 10.8\%; post $9.1 \%$ ), Communism (pre 11.4\%; post 9.5\%) and Castro (pre 10.3\%, post $8.6 \%)$.

The categories were assigned a valence-positive (3), neutral (2) and negative (1). An independent samples $t$-test found significant differences between pre-announcement and postannouncement groups in terms of mean valence of mentions $\left(M_{\text {pre }}=1.60 ; M_{\text {post }}=1.69\right)$. Though a positive shift was noted, overall valence remained in negative territory. See Table 3 for words, valences and percentages of total mentions.

\section{Discussion}

The capture of multiple dimensions of U.S. citizens' knowledge and sentiment before and after the historic announcements about the resumption of U.S.-Cuba diplomatic relations provides a unique contribution to the literature on soft power. Viewed against the framework of the Model of Country Concept (Fullerton and Kendrick, 2017), one can observe multiple integrants of country concept at play in the U.S.-Cuba attitudinal equation, including previous military hostility (man-made disasters), foreign policy, historical relationships, immigration and the veritable absence of cultural and brand export exchanges for the past 50 years.

The theory of agenda setting highlights the mechanism by which the salience of issues, or objects, is transferred from the media to the public. Of the several possible outcomes of this salience, the current study focused first on U.S. citizens' selfreported or perceived knowledge about Cuba. Indeed Americans believed they knew significantly more about Cuba after the announcements than they did before. Because the difference was significant and also correlated with an almost two-fold increase in Cuba-related media content, and because there appears to be no competing explanation for higher perceived levels of knowledge about this "shell of a topic" (Kosicki, 1993), it follows that the media, in executing its role in first-level agenda setting, influenced the cognitive aspect of issue salience among the public. This finding is in concert with the large body of research that demonstrates first-level agenda-setting effects.

With respect to second-level agenda setting, the case of Cuba and the integrant of media content in the form of U.S. reportage and global social media content is unique. Fifty years of hostility and scant communication between the United States and Cuba, as well as pervasively negative news coverage since the Revolution of 1959 , gave way to glimpses of cooperation, respect and reconciliation at the end of 2014. When the post-announcement survey reported here was fielded in May 2015, the news appeared to focus on the re-establishment of political diplomatic relations and the potential for future travel and economic negotiations. Although the current study does not offer a precise quantitative analysis of media coverage and content about developments in U.S.-Cuba relations before and after the December 2014 announcements, on-line search of news archives revealed substantial increases in coverage of Cuba in the U.S. media. To the extent that the "climate of opinion" or tone created by the media (Noelle-Neumann and Mathes, 1987) during the coverage of the U.S.-Cuba diplomatic announcements was positive or positive-leaning, as it appeared to be, then it may come as no surprise that public attitudes followed suit, as the current study described. Taken together, these indicators of attitudes toward Cuba, its people and government demonstrate aspects of second-level agenda setting.

\section{Table 3 | Three words provided by respondents to describe} Cuba

\begin{tabular}{|c|c|c|}
\hline Category & $\begin{array}{l}\% \text { Mentions pre } \\
\text { announcement }(n=787)\end{array}$ & $\begin{array}{l}\% \text { Mentions post } \\
\text { announcement }(n=718)\end{array}$ \\
\hline \multicolumn{3}{|l|}{ Positive responses } \\
\hline Beautiful & 3.4 & 2.1 \\
\hline Overall Positive & 0.3 & 1.5 \\
\hline Diversity & 0.1 & 0.1 \\
\hline Happy & 1.1 & 1.8 \\
\hline Interesting & 2.0 & 0.9 \\
\hline Vintage & 2.0 & 3.5 \\
\hline Colourful & 0.5 & 0.7 \\
\hline Heritage & 0.5 & 0.1 \\
\hline Calm/Relaxing & 0.4 & 0.0 \\
\hline Entertaining & 2.2 & 3.1 \\
\hline Fun & 0.3 & 0.6 \\
\hline Other Positive & 0.8 & 2.1 \\
\hline Total Positive & $13.6 \%$ & $16.5 \%$ \\
\hline \multicolumn{3}{|l|}{ Neutral Responses } \\
\hline Food/Alcohol & 5.0 & 5.0 \\
\hline Recreation & 1.1 & 0.7 \\
\hline Immigrant & 1.1 & 0.7 \\
\hline Natural Elements & 3.4 & 5.4 \\
\hline Climate & 4.1 & 5.6 \\
\hline Celebrities & 1.7 & 0.6 \\
\hline Cigars & 10.8 & 9.1 \\
\hline Foreign/ & 3.3 & 2.5 \\
\hline \multicolumn{3}{|l|}{ Foreigners } \\
\hline Locations & 1.0 & 0.4 \\
\hline Other Neutral & 1.3 & 4.6 \\
\hline Culture & 0.9 & 1.8 \\
\hline Total Neutral & $33.7 \%$ & $36.4 \%$ \\
\hline \multicolumn{3}{|l|}{ Negative Responses } \\
\hline Policies & 3.3 & 2.6 \\
\hline Dictator(ship) & 2.8 & 3.2 \\
\hline Conflict & 1.1 & 2.1 \\
\hline Poverty & 7.2 & 5.7 \\
\hline Control & 4.7 & 2.8 \\
\hline Isolated & 1.3 & 1.4 \\
\hline Fearful & 0.8 & 0.6 \\
\hline No desire to visit & 0.4 & 0.1 \\
\hline Dangerous & 5.5 & 3.8 \\
\hline Strict & 1.1 & 1.0 \\
\hline Sad & 0.0 & 0.7 \\
\hline Castro & 11.4 & 9.5 \\
\hline Communism & 10.3 & 8.6 \\
\hline Socialist & 0.4 & 0.1 \\
\hline Bay of Pigs & 0.2 & 0.7 \\
\hline Missile(s) & 0.0 & 0.0 \\
\hline Anti-American & 1.0 & 0.6 \\
\hline Other Negative & 0.6 & 3.8 \\
\hline Total Negative & $52.1 \%$ & $47.3 \%$ \\
\hline
\end{tabular}

Significant positive upticks in favorability ratings toward the Cuban government and people were noted after the presidential announcements and, as is often the case for these variables (see for example, Fullerton and Kendrick, 2013), attitudes toward the Cuban people were more favourable than those toward the government. These findings mirror shifts in Gallup polls taken in the United States in 2014 and 2015 (Norman, 2016), though Gallup measures country attitudes unilaterally by way of a question about favorability toward "the country" of Cuba in general.

This study gauged country concept using measures of both country image and country reputation. With respect to country image, measured by the valence of the three words respondents associated with Cuba, post-announcement measures showed small but significant shifts in a positive direction, though overall 
valence for country image remained in negative territory at 1.69 on a 3 -point scale ( $1=$ negative, $2=$ neutral, $3=$ positive). Did the absence of a "bad boy" political foe like Fidel Castro in a formal leadership role in 2014 and 2015 result in a cascade of largely positive news? And does this preponderance of the positive do less to move the needle of public sentiment than a military threat or other negative development would?

For country reputation, dimensions of leadership and culture both showed significantly higher evaluations post-announcement, with both measures moving from overall below-average ratings to above average. Again, the Culture dimension was rated higher than the Leadership dimension both pre- and post-test, which if taken together with the results of the favorability ratings toward the Cuban government and people, lend conceptual credence to the importance of separating perceptions of political leaders from those of "people."

Limitations and suggestions for future research. Agenda-setting studies, because they involve numerous and often disparate measures of media content, issue salience and public opinion, are subject to limitations. The current study is no exception. The inability to access a formal content analysis of either objects or attributes of the coverage of Cuba available for the time period in question made precise characterization of media content difficult. The current study focused on the increased volume of media content as well as its overall positive focus as extant stimuli for the agenda-setting phenomenon.

The shift in U.S. and Cuban foreign policy was so relatively sudden and extreme that it will be instructive if future research could examine whether the short-term improvements in attitudes toward Cuba withstand the longer-term reality of implementing the changes foreshadowed by the announcements. If vacation and pleasure travel are re-instated to Cuba, future research could explore whether the views of Americans who have finally visited the forbidden country change once they experience first-hand a land and a culture they had only known through the lens of media content. Such a study would further illuminate the interplay of multiple integrants that influence citizens' notions of nations, as delineated in the Model of Country Concept.

A study of Cubans' concept of the United States could also reveal effects of mediated exposure to the U.S. How might the salience equation be rewritten on a personal level as the pictures in the heads of both Americans and Cubans resulting from recent media content of soft power activities including coverage of President Obama's historic visit to Cuba, reconcile with tourism and people-to-people experiences they may have with each other in the future? Future research regarding the evolution of U.S. and Cuban relations, and particularly the actions of a new U.S. presidential administration beginning in 2017, could shed light on this phenomenon. A closer look at the dynamics of generational differences, as well as other demographic variables, on attitudes toward Cuba could be instructive, as would a deeper analysis of different types of media outlets of their coverage of Cuba.

\section{Conclusion}

The case of Cuba and the warming of diplomatic relations with the U.S. after more than 50 years of hostility is an example of soft power in action. The U.S./Cuban situation studied herein might be viewed as a timely "petri dish" in which to analyze elements of soft power as they continue to unfold between two countries that had little contact prior to 2014. The use of soft power by the United States, as described in this study, may not only have been for the benefit of achieving U.S. objectives in Cuba, but also for the benefit of winning hearts and minds at home and abroad. The singular strategy of isolation that the U.S. employed for more than 50 years with Cuba may have tarnished the country concept of the United States with its allies in Europe, South America and elsewhere who had no such animosity toward Cuba. By extending the hand of friendship across the Florida Straits, President Obama may have used soft power to endear our friends in other countries and improve U.S. Country Concept-if even for a short time. How this strategy will play out in the complex world of international relations remains to be seen, particularly given that President Trump's administration has not yet articulated its role in the next chapter of U.S.-Cuba relations.

\section{References}

Ahmed A and Davis J (2015) U.S. and Cuba reopen long-closed embassies, New York Times 20 July, http://www.nytimes.com/2015/07/21/world/americas/cubaus-embassy-diplomatic-relations.html?_r = 0, accessed 22 July 2015.

Baran S and Davis DK (2015) Mass Communication Theory: Foundations, Ferment, and Future. Cengage Learning: Stamford, CT.

Barringer F (2000) The Elian Gonzalez case; the hometown newspaper; newspaper in sea of outrage over coverage of Elian case. The New York Times, http://www. nytimes.com/2000/04/24/us/elian-gonzalez-case-hometown-newspaper newspa per-sea-outrage-over-coverage-elian.html.

Bolender K (2015) Is the US media softening its line on Cuba? Cuba Solidarity (Summer), http://www.cuba-solidarity.org.uk/cubasi/article/191/is-the-us-mediasoftening-its-line-on-cuba.

Bogart Leo (1995) Cool Words, Cold War: A new Look at USIA's Premises for Propaganda, Revised edn, American University Press: Washington DC.

Cave D (2016) With Obama's visit to Cuba, old battle lines fade. New York Times. p. 6 .

Cuban Research Institute. (2014) Florida International University Cuba Poll: How Americans in Miami view U.S. policies toward Cuba, Florida International University: Miami, FL.

Davis JH (2015) "U.S. removes Cuba from the state-sponsored terrorism list" New York Times, https://www.nytimes.com/2015/05/30/us/us-removes-cuba-fromstate-terrorism-list.html?_r $=0$.

Davis JH (2016a) Obama plans visit to Cuba, as talks on expanding trade begin. The New York Times, http://www.nytimes.com/2016/02/18/us/politics/newtalks-begin-with-cuba-on-expanding-business-ties.html?_r $=0$.

Davis JH (2016b) "Fate of the U.S-Cuba thaw is less certain under Donald Trump" New York Times, http://www.nytimes.com/2016/11/26/us/politics/us-cuba-rela tions-fidel-castro-donald-trump.html.

DeYoung K (2014) Obama moves to normalize relations with Cuba as American is released by Havana, Washington Post, Retrieved from http://www.washington post.com/world/-security/report-cuba-frees-american-alan-gross-after-5-yearsdetention-on-spy-charges/2014/12/17/a2840518-85f5-11e4-a702-fa31ff4ae98e story.html.

De Moraes Lisa (2015) Conan in Cuba crowd hits 3.7 million. Deadline Hollywood, http://deadline.com/2015/04/conan-in-cuba-ratings-13-7-million-viewersvideo-1201410450/.

Federal Register. (2015) Cuban assets control regulations, Washington DC, https:// www.federalregister.gov/articles/2015/01/16/2015-00632/cuban-assets-controlregulations.

First flight in half century from US to Cuba set to take off. (2016) The Financial Express, http://search.proquest.com/docview/1815429332?accountid =3320).

Frank M (2016) Cuba's Fidel Castro knocks sweet-talking Obama after "honeycoated" visit. Reuters, http://www.reuters.com/article/us-usa-cuba-castroidUSKCN0WU18I.

Frumin A and Margolin E (2014) From 'I Love Lucy' to pop music, Cuba's influence on America runs deep. MSNBC.com, http://www.msnbc.com/msnbc/ i-love-lucy-pop-music-cubas-influence-america-runs-deep.

Fullerton J and Kendrick A (2013) Strategic uses of mediated public diplomacy: International reaction to US tourism advertising. American Behavioral Scientist; 57 (9): 1332-1349. doi: 10.1177/0002764213487737.

Fullerton J and Kendrick A (2017) Shaping International Public Opinion: A Model for Nation Branding \& Public Diplomacy. Peter Lang Publishing: New York.

Glenza Jessica (2015) Netflix launches \$7.99 service for Cuba despite average wage of $\$ 17$ a month. The Guardian, https://www.theguardian.com/world/2015/feb/ 09/netflix-launches-streaming-service-cuba.

Goldberg Jeffrey (2016) The road to Havana. The Atlantic, https://www.theatlantic com/international/archive/2016/03/united-states-cuba-obama-visit/474510/.

Gomez A (2016) "Obama lifts restrictions on Cuban rum, cigars," USA Today, http://www.usatoday.com/story/news/world/2016/10/14/obama-cuba-regula tions-expands-trade-travel-rum-cigars/92042662/.

Gorman B and Seguin C (2015) Reporting the international system: attention to foreign leaders in the US news media 1950-2008. Social Forces; 94 (2): 775-799. 
Groshek J, Guo L, Cutino C and Elasmar M (2015) A Sample Methodology for Extracting and Interpreting Country Concept from Social Media Users and Content. Paper presented at the Symposium on Nation Branding \& Public Diplomacy, 5 August 2015 in San Francisco, CA.

Iyengar S and Kinder DR (1987) News that matters: Television and American Opinion. University of Chicago Press: Chicago, IL.

Kornbluh P, LeoGrande WM and Levy P (2015) Cuba confidential. Mother Jones; 40 (5): 44.

Kosicki GM (1993) Problems and opportunities in agenda-setting research. Journal of Communication; 43 (2): 100-127.

Leatherby L (2015) Republicans stand against Cuba change despite public opinion shift. National Public Radio.

LeoGrande William M. and Kornbluh Peter (2014) Back Channel to Cuba: The Hidden History of Negotiations between Washington and Havana. University of North Carolina Press: Chapel Hill, NC.

Lippmann W (1922) Public Opinion. Hartcourt, Brace and Company: New York. McCombs M and Shaw D (1972) The agenda-setting function of mass media. Public Opinion Quarterly; 36 (2): 176-187.

McCombs M and Shaw D (1974) A progress report on agenda-setting research. Paper presented the Annual Meeting of the Association for Education in Journalism, San Diego, CA, 18-21 August.

McKinley J (2008, February 20) Fidel Castro Resigns as Cuban President. New York Times, http://www.nytimes.com/2008/02/20/world/americas/20castro.html? $\mathrm{r}=0$.

Moon SJ (2011) Attention, attitude and behavior: Second-level agenda-setting effects as a mediator of media use and political participation. Communication Research; 38, 1-22.

Moss C (2016) "Can I still Travel to Cuba following Fidel Castro's Death?" The Telegraph, http://www.telegraph.co.uk/travel/advice/cuba-travel-fidel-castro-death/.

Neill M (2008) Raul Castro pushes change for Cubans. CNN Edition, 26 April, http://edition.cnn.com/2008/WORLD/americas/04/26/raul.castro/.

Noelle-Neumann E and Mathes R (1987) The 'event as event' and the 'event as news': The significance of 'consonance' for media effects research. European Journal of Communication; 2 (4): 391-214.

Norman J (2016) Majority of Americans view Cuba favorably for first time. Gallup (15 February), http://www.gallup.com/poll/189245/majority-americans-viewcuba-favorably-first-time.aspx.

Nye JS Jr (2004) Soft Power: The Means to Success in World Politics. Public Affairs: New York.

O'Day JC (2015) Side-By-Side coverage of Cuba and Iran highlights shift in U.S. media villain-making. Fairness \& Accuracy in Reporting, 24 July, http://fair.org/ home/side-by-side-coverage-of-cuba-and-iran-highlights-shift-in-us-media-vil lain-making/.

Palmer JL (2011) Gender, nation, and transnationalism: Representations of Cuba in U.S. newsmagazines (Time and Newsweek: 1959-2010). Unpublished thesis. University of Georgia, https://getd.libs.uga.edu/pdfs/palmer_jamie_1_201105_ ma.pdf.

Partlow J and Craighill P (2015) Poll shows vast majority of Cubans welcome close ties with U.S. Washington Post, https://www.washingtonpost.com/world/the americas/poll-shows-vast-majority-of-cubans-welcome-closer-ties-with-us/ 2015/04/08/6285bfe4-d8c3-11e4-bf0b-f648b95a6488_story.html?utm_term=. $46 \mathrm{~d} 7 \mathrm{fdd} 4 \mathrm{~d} 658$.

Perez LA (1990) Cuba and the United States: Ties of Singular Intimacy. University of Georgia Press: Athens, Greece.

Pérez LA (2008) Cuba in the American Imagination: Metaphor and the Imperial Ethos. University of North Carolina Press.

Perez LA (2016) The United States reengages Cuba: The habit of power. American University Center for Latin American American and Latino Studies, Washington DC.
Passow T, Fehlmann R and Grahlow H (2005) Country reputation-From measurement to management: The case of Lichtenstein. Corporate Reputation Review; 7, 309-326.

Pew Research Center. (2010) Pew Global Attitudes Project, Washington DC, http:// pewglobal.org

Robles F (2016) Despite renewed ties with U.S., Cuban dissidents are just as vulnerable. New York Times, http://www.nytimes.com/interactive/projects/cp/ international/obama-in-cuba/type/analysis.

Soderlund WC, Surlin SH and Wagenberg RH (1998) The impact of the end of the cold war on Canadian and American TV news coverage of Cuba: Image consistency or image change? Canadian Journal of Communication, 23(2) Spring, http://proxy.libraries.smu.edu/login?url = http://search.proquest.com/ docview $/ 219561547$ ? accountid $=6667$.

Suddath C (2009) A brief history of U.S.-Cuba relations. Time, http://content.time. com/time/nation/article/0,8599,1891359,00.html

Sussman D (2016) Most Americans support ending Cuba embargo, Times poll finds. New York Times, http://www.nytimes.com/interactive/projects/cp/inter national/obama-in-cuba/type/analysis.

U.S. Cuba Relations: Continuing coverage of the restoration of diplomatic relations between the United States and Cuba (2016) http://www.nbcnews.com/storyline/ u-s-cuba-relations.

Whitefield M (2014, February 11) Cuba poll reflects changing political landscape in Florida. The Miami Herald, http://www.miamiherald.com/news/business/inter national-business/article1960257.html\#!

Yang S, Shin H, Lee J and Wrigley B (2008) Country reputation in multidimensions: Predictors, effects, and communication channels. Journal of Public Relations Research; 20 (4): 421-440.

Zhang C and Meadows CW (2012) International coverage, foreign policy, and national image: exploring the complexities of media coverage, public opinion, and presidential agenda. International Journal of Communications; 6, 76-95.

\section{Data availability}

The datasets generated during and/or analyzed during the current study are not publicly available because of university Institutional Review Board restrictions on the privacy and anonymity of respondents. However data are available from the corresponding author on reasonable request.

\section{Additional information}

Competing interests: The authors declare that they have no competing financial interests.

Reprints and permission information is available at http://www.palgrave-journals.com/ pal/authors/rights_and_permissions.html

How to cite this article: Fullerton J, Kendrick A and Broyles S (2017) Attitude change among U.S. adults after the Castro-Obama announcement: the role of soft power in agenda setting. Palgrave Communications. 3:17018 doi: 10.1057/palcomms.2017.18.

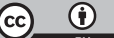

This work is licensed under a Creative Commons Attribution 4.0 International License. The images or other third party material in this article are included in the article's Creative Commons license, unless indicated otherwise in the credit line; if the material is not included under the Creative Commons license, users will need to obtain permission from the license holder to reproduce the material To view a copy of this license, visit http://creativecommons.org/licenses/by/4.0/ 